\title{
Pendampingan Belajar Di Rumah Selama Masa Pandemi Covid-19
}

\author{
Lutfiyah $^{1 *}$, Evi Roviati ${ }^{2}$ \\ IAIN Syekh Nurjati Cirebon \\ 1e-mail: Lutfiyahlutfiyah0@gmail.com \\ 2e-mail: akademik.roviati@gmail.com \\ *Corresponding Author
}

\begin{abstract}
ABSTRAK
World Health Organization (WHO) telah mengumumkan virus corona atau covid-19 sebagai pandemi, yaitu keadaan dimana populasi di seluruh dunia memiliki peluang dapat terjangkit atau terkena infeksi. Keadaan ini tentunya juga berdampak pada perekonomian Indonesia yang secara langsung juga berdampak pada dunia pendidikan di Indonesia. Mengingat pandemi ini adalah suatu musibah yang mendadak sehingga mengakibatkan kebijakan atau keputusan yang diambil secara cepat tanpa adanya persiapan yang matang membuat guru, siswa, dan orang tua merasa kebijakan tersebut kurang efektif terutama bagi sebagian siswa yang teknik pembelajarannya tidak terbiasa dengan daring. Untuk itu Kegiatan pengabdian masyarakat ini sebagai sarana penyampaian kebermanfaatan ilmu dan rasa kepedulian para mahasiswa terhadap masyarakat dibidang pendidikan dalam bentuk pendampingan belajar melalui kegiatan bimbingan belajar di rumah. Tujuan dari kegiatan ini untuk tetap mengefektifkan dan memaksimalkan dari tujuan pembelajaran di sekolah. Program ini dilaksanakan pada daerah yang telah terkonfirmasi zona hijau oleh pemerintah setempat. Kegiatan ini melibatkan siswa Paud/Tk sampai dengan siswa SD/MI berjumlah 56 orang. Metode pelaksanaan kegiatan secara deskriptif kualitatif. Hasil kegiatan menunjukkan prestasi dan motivasi belajar siswa mengalami perkembangan yang baik. Perlunya perbaikan fasilitas dalam keberlanjutan pelaksanaan program kegiatan bimbingan belajar sehingga siswa lebih nyaman dalam belajar.
\end{abstract}

Kata Kunci: Covid-19, Pembelajaran Daring, Pendampingan Belajar

\begin{abstract}
The World Health Organization (WHO) has announced the corona virus or covid-19 as a pandemic, which is a situation in which populations around the world have a chance to be infected or infected. This situation of course also has an impact on the Indonesian economy which directly impacts the world of education in Indonesia. Given that this pandemic is a sudden disaster that results in policies or decisions being taken quickly without proper preparation, teachers, students and parents feel that the policy is ineffective, especially for some students whose learning techniques are not familiar with online. For this reason, this community service activity is a means of conveying the usefulness of knowledge and a sense of student concern for the community in the field of education in the form of learning assistance through home tutoring activities. The purpose of this activity is to keep the effectiveness and maximize the learning objectives in school. This program is implemented in areas that have been confirmed as green zones by the local government. This activity involved 56 kindergarten school students and elementary school students. The method of implementing activities is descriptive qualitative. The results of the activity show that student achievement and learning motivation have developed well. The need for improved facilities in the sustainable implementation of the tutoring activity program so that students are more comfortable in learning.
\end{abstract}

Keywords: Covid-19, Online Learning, Learning Assistance 


\section{PENDAHULUAN}

Ditengah merebaknya wabah virus corona atau covid 19 yang selain menyebabkan pertahanan dan keamanan dunia terguncang, juga berdampak pada aktivitas sosial,ekonomi, politik, dan pendidikan diseluruh dunia. World Health Organization (WHO) dalam (Siyahailatua \& Tarigan, 2020) telah mendeklariskan virus corona atau covid-19 sebagai pandemi yang didefinisikan sebagai situasi ketika populasi di seluruh dunia memiliki peluang dapat terjangkit atau terkena infeksi.

Work From Home (WFH) adalah salah satu cara untuk memutus penyebaran covid-19 sebagaimana yang telah dikeluarkan oleh pemerintah melalui Surat Edaran Menteri Pendayagunaan Aparatur Negara dan Reformasi Birokrasi (PAN \& RB) Nomor 50/2020 tentang Perubahan Kedua atas Surat Edaran Menteri PAN \& RB Nomor 19/2020 tentang Penyesuaian Sistem Kerja Aparatur Sipil Negara dalam Upaya Pencegahan Penyebaran Covid-19 di Lingkungan Instansi Pemerintah. Dalam dunia pendidikan dikenal dengan School From Home (SFH) peraturan ini wajib diikuti terutama pada daerah yang telah terkonfirmasi zona merah. Dengan menerapkan SFH berarti kita menggunakan sistem pembelajaran jarak jauh yaitu dengan menggunakan dan memanfaatkan teknologi digital berupa media online berbasis multimedia. Beberapa teknologi digital yang dapat digunakan untuk menunjang jalannya pendidikan tetap dirumah saja seperti; Whatsapp, Zoom, Google Class Room (GCR), Facebook, dan masih banyak lagi.

Pemilihan media pembelajaran tentunya bergantung dengan apa yang mau diukur atau dinilai dari sebuah capaian subjek akademik. Sedangkan Materi diberikan biasanya dalam bentuk powerpoint, video singkat, dan bahan bacaan. Mengingat adanya Permendikbud yang memberikan pesan bagaimana pentingnya proses pembelajaran harus mengandung subtansi pendidikan nilai, pendidikan karekater, dan pendidikan yang dapat mendorong terwujudnya sumber daya manusia Indonesia yang memiliki kompetensi abad 21 yang unggul dan kompetitif membuat guru harus mampu mendesain media pembelajaran sebagai bentuk inovasi dari memanfaatkan pembelajaran secara daring.

Hal ini tentunya membuat beban guru semakin berat, pertama karena pandemi ini terkesan musibah yang mendadak sehingga peralihan sistem pembelajaran daring belum ada persiapan yang matang baik dari segi metode maupun rancangan pembelajaran. Kedua, karena segala faktor pendukung atau akses jalannya pembelajaran daring yang sulit seperti akses internet yang membutuhkan biaya yang tinggi bagi guru untuk tetap menjalankan pembelajaran secara daring. Kedua faktor inilah yang kemudian menjadi penyebab tidak efektifnya pembelajaran daring. Karena bertolak belakang dengan ciri-ciri keefektifan itu sendiri seperti; berhasil mengantarkan 
siswa mencapai tujuan-tujuan instruksional yang telah ditentukan, memberikan pengalaman belajar yang atraktif, melibatkan siswa secara aktif sehingga menunjang pencapaian tujuan instruksional dan memiliki sarana-sarana yang menunjang proses belajar mengajar.

Keadaan ini diperkuat dengan fakta yang terjadi dilapangan, banyak orang tua dan siswa menjerit lantaran susahnya mendampingi dan mendidik anak mereka dalam sistem pembelajaran secara daring ini. Salah satu dampak penurunan yang sangat terasa yaitu pentransferan ilmu oleh guru di sekolah yang mengakibatkan penurunan kognitif pada anak, selain itu juga terjadinya penurunan yang tidak sesuai dengan pesan Bapak Pendidikan Idonesia Ki Hajar Dewantara, “pembelajaran yang menerapkan nilai-nilai dengan memberi keteladanan (ing ngarso sung tulodo), membangun kemauan (ing madyo mangun karso), dan mengembangkan kreativitas peserta didik dalam proses pembelajaran (tut wuri handayani).

Bimbingan belajar merupakan salah satu usaha pendampingan belajar yang dipilih oleh siswa untuk menunjang prestasi akademik siswa. Dwi menyimpulkan hasil penelitiannya bahwa bimbingan belajar merupakan solusi alternatif bagi siswa yang merasa materi di sekolah belum cukup atau tidak diajarkan oleh guru (Dwi, 2013). Rosaria dan Novika juga menyimpulkan dalam jurnal penelitiannya, Kegiatan bimbingan belajar ini dapat membantu meningkatkan prestasi dan motivasi belajar siswa (Rosaria \& Novika, 2017). Adapun pengabdian yang dilakukan oleh Santoso \& Rusmawati dalam jurnalnnya yang berjudul "Pendampingan Belajar Siswa Di Rumah Melalui Kegiatan Bimbingan Belajar Di Desa Guci Karanggeneng Lamongan” menjadikan bimbingan belajar di rumah sebagai salah satu cara alternatif untuk meningkatkan prestasi dan motivasi belajar siswa desa Guci Karanggeneng, dengan kondisi geografis desa tersebut yang jauh dengan pusat kota dan mahalnya biaya bimbingan belajar membuat para dosen Univesitas Islam Lamongan tergerak untuk melakukan kegiatan pengabdian membangun program bimbingan belajar (Santoso \& Rusmawati, 2019). Oleh sebab itu penulis juga tertarik untuk membantu anakanak dan orang tua dalam mendampingi belajar selama masa pandemi ini dengan tujuan dari untuk tetap mengefektifkan dan memaksimalkan dari tujuan pembelajaran di sekolah.

\section{BAHAN DAN METODE}

Pendampingan belajar siswa melalui kegiatan bimbingan belajar ini dilaksanakan di lembaga yayasan AL-AZIZ. yang berlokasi di Rorotan III Jakarta Utara, daerah ini terkonfirmasi zona hijau oleh pemerintah setempat sehingga kami berani melakukan Kegiatan tatap muka sebagai salah satu bentuk pengabdian yang dibutuhkan masyarakat pada masa pandemi sekarang ini dengan tetap memperhatikan protokol kesehatan. Dengan jumlah seluruh siswa 56 siswa dengan rincian kelas Paud- TK tiga belas siswa, dibagi menjadi dua kelas. Kelas 1 SD sebanyak 
sembilan siswa, dibagi menjadi dua kelas. kelas 2 SD sebanyak lima siswa. Kelas 3 SD sebanyak sepuluh siswa, dibagi menjadi dua kelas. Kelas 4 SD sebanyak lima siswa. Kelas 5 SD sebanyak delapan Siswa, dibagi menjadi dua kelas. Dan kelas 6 SD sebanyak lima siswa. Kegaitan pembelajaran mengikuti protokol kesehatan dari pemerintah seperti penagaturan tempat duduk berjarak dua meter, menyiapkan tempat cuci tangan, menggunakan face shield dan masker. Mengingat keterbatasan tempat pembelajaran dibagi menjadi beberapa sesi yaitu : (1) sesi pertama untuk kelas Paud/Tk, kelas 1 dan 2 pada pagi hari dari pukul 08.00 s/d 10.00. (2) sesi kedua untuk kelas 3 dan 4 pada pukul $10.00 \mathrm{~s} / \mathrm{d}$ 12.00. (3) sesi ketiga untuk kelas 5 dan 6 pada pukul $14.00 \mathrm{~s} / \mathrm{d}$ 17.00. Adapun mata pelajaran yang dibimbing hanya berfokus pada mata pelajaran yang dianggap terlalu sukar untuk dimengerti (berdasarkan kuesioner) seperti matematika, IPA, dan agama. Akan tetapi, siswa bisa menanyakan mata pelajaran lain apabila siswa mengalami kendala dalam materi.

Dasar pemilahan kelas berdasarkan tingkatan kelas siswa di sekolah, hal ini dimaksudkan agar dapat menyeragamkan materi pelajaran sehingga akan lebih efisien. Fasilitas yang digunakan untuk menunjang pelaksanaan kegiatan adalah meja panjang, papan tulis sederhana, alat tulis menulis, buku pelajaran siswa, dan beberapa makanan ringan (snack) dan permen sebagai reward (hadiah) untuk siswa. Pelaksanaan kegiatan ini dilakukan selama bulan Juli 2019, pada pukul 08.00 hingga 17.00 WIB.

Pelaksanaan kegiatan bimbingan belajar ini menggunakan lima tahapan, yaitu: (1) Belajar dimulai dengan berdoa bertujuan untuk menumbuhkan pada siswa untuk segala sesuatu yang baik harus melibatkan tuhannya (2) Pemberian motivasi siswa, hal ini bertujuan untuk membangkitkan semangat belajar melalui cerita inspiratif maupun kata kata mutiara hikmah (3) Penjelasan materi, kegiatan belajar mengajar dengan berbagai metode belajar, yang kami terapkan adalah metode jigsaw dan pameran. Salah satu tujuan kami menerapkan metode ini selain agar suasana belajar monoton yaitu bisa melatih public speaking siswa dan juga melatih kerja sama antar siswa (4) Tanya jawab hal ini bertujuan untuk mengetahui kedalaman pemahaman siswa akan materi

(5) Permainan berupa kuis individu dan cerdas cermat berkelompok, (6) Pemberian reward (hadiah) berupa pujian/penghargaan secara lisan dan berupa barang. Metode penelitian pelaksanaan kegiatan ini secara deskriptif kualitatif.

Teknik pengumpulan secara tes, non tes dan kuesioner. Secara tes untuk mengetahui perkembangan prestasi belajar siswa, dan secara non tes dengan wawancara dan menggunakan lembar observasi untuk mengetahui motivasi belajar siswa, dan kuesioner untuk mengukur kepuasan siswa pada program pendampingan belajar ini. Jenis data dalam penelitian ini tergolong data kualitatif. Teknik analisa data secara naratif deskriptif. 


\section{HASIL DAN PEMBAHASAN}

Hasil dari kegiatan pengabdian ini berupa pendampingan siswa melalui kegiatan bimbingan belajar yang dilaksanakan di yayasan Al-AZIZ yang berlokasi di Rorotan III Jakarta Utara, daerah ini terkonfirmasi zona hijau oleh pemerintah setempat sehingga kami berani melakukan Kegiatan tatap muka sebagai salah satu bentuk pengabdian yang dibutuhkan masyarakat pada masa pandemi sekarang ini. Pengabdian ini merupakan salah satu program pengabdian masyarakat bagi mahasiswa sebagai upaya pelaksanaan kegiatan kuliah kerja nyata $(\mathrm{KKN})$. Kegiatan pengabdian kepada masyarakat ini memberikan banyak manfaat, wawasan dan pengetahuan kepada anak-anak terutama dalam meningkatkan prestasi dan motivasi belajar.

Pelaksanaan kegiatan bimbingan belajar ini menggunakan 6 tahapan, yaitu: (1) Kerelegiusan, belajar dimulai dengan berdoa bertujuan untuk menumbuhkan pada siswa untuk segala sesuatu yang baik harus melibatkan tuhannya (2) Pemberian motivasi siswa, sebagaimana dalam (Bakhri, dkk, 2020) motivasi merupakan usaha-usaha yang dapat mendorong dan menyebabkan seseorang baik secara sadar maupun tidak sadar untuk tergerak melakukan suatu keinginan agar tercapainya tujuan ataupun kepuasan atas perbuatannya. Oleh sebab itu, pemberian motivasi pada siswa bertujuan untuk membangkitkan semangat belajar melalui cerita inspiratif maupun kata kata mutiara hikmah (3) Penjelasan materi, kegiatan belajar mengajar dengan berbagai metode belajar, yang kami terapkan adalah metode jigsaw dan pameran dan metode ceramah. Salah satu tujuan kami menerapkan metode ini selain agar suasana belajar monoton yaitu bisa melatih public speaking siswa (4) Tanya jawab hal ini bertujuan untuk mengetahui kedalaman pemahaman siswa akan materi(5) Permainan berupa kuis individu dan cerdas cermat berkelompok, (6) Pemberian reward (hadiah) berupa pujian/penghargaan secara lisan dan berupa barang.

Tahap relegius dalam belajar melalui berdoa serta hafalan surat pendek, hal ini bertujuan selain menciptakan generasi yang cerdas juga menjadi generasi yang religius dan mempunyai karakter luhur. Berdoa dan hafalan surat berada pada awal kegiatan sebelum kegiatan belajar dimulai.

Tahapan motivasi melalui dua cara, yaitu: (1) Melalui pendekatan motivasi materi pelajaran yaitu dengan memberikan dan mengkaitkan materi dengan kehidupan sehari-hari, hal ini bertujuan untuk merangsang daya kekaguman dan ketertarikan siswa terhadap pelajaran yang akan dipelajari. Selain itu, karena belajar akan bermakna apabila materi yang dipelajari pernah dialami oleh siswa (belajar dari pengalaman). (2) Pendekatan motivasi melalui cerita inspiratif seperti proses tokoh-tokoh ilmuan dalam menggapai tujuan, ilmu atau penemuannya sekarang bisa bermanfaat untuk seluruh manusia didunia. Selain itu, dapat berasal dari cerita pengalaman pengajar sendiri seperti pengalaman berhasil mendapat juara kelas selama masa sekolah SMP- 
SMA padahal seaktu sekolah SD hampir tidak naik kelas. Juga dengan motivasi atau kata kata dalam baitbait hikmah yang bertujuan untuk membangkitkan semangat belajar siswa, semangat dalam menggapai citacita, dan terutama semangat dalam melanjutkan pendidikan kejenjang yang lebih tinggi. Biasanya tahapan ini akan diterapkan ditengah-tengah pembelajaran.

Tahapan penjelasan materi berisi penjelasan dari pemateri atau pengajar dengan berdasarkan acuan buku kurikulum 2013 yang telah direvisi untuk jenjang SD/MI. Untuk jenjang Paud-TK materi disesuaikan dengan kebutuhan mereka sebagai penunjang pelajaran pra SD seperti membaca dan calistung. Adapun metode penjelasan materi yang diterapkan adalah metode jigsaw, pameran dan metode ceramah. Metode ceramah pada dasarnya sama dengan penjelasan pengajar pada umumnya. Metode jigsaw dimana siswa dibentuk perkelompok lalu dipilih satu orang dalam beberapa kelompok sebagai perwakilan yang ditunjuk sebagai tamu untuk menerima materi dari kelompok lainnya dan bertanggung jawab untuk menjelaskan materi yang didapat dari kelompok lain untuk disampaikan kepada kelompoknya sendiri, sedangkan anggota kelompok yang lainnya menguasai materi yang sudah ditentukan untuk kemudian dijelaskan pada tamu yang berkunjung untuk meminta pejelasan materi. Selain jigwsaw saya juga menerapkan teknik pameran hampir sama dengan jigsaw perbedaannya materi divisualisasikan dan yang menjaga stand wajib menjelaskan materi. Metode ini diterapkan dengan tujuan agar suasana pembelajaran lebih hidup sekaligus dapat melatih public speaking siswa dan melatih kerja sama.

Hal ini sejalan dengan hasil penelitian Pangestika dan Ratnaningsih, hasil dari penelitian eksperimen semu ini adalah adanya perbedaan kemampuan public speaking mahasiswa PGSD antara kelas yang menggunakan model pembelajaran kooperatif tipe Jigsaw dengan kelas yang menggunakan metode ceramah. Kelas ekperimen mempunyai skor yang lebih tinggi dibandingkan kelas kontrol dapat disimpulkan bahwa model pembelajaran kooperatif tipe Jigsaw lebih baik dibandingkan metode ceramah (Pangestika \& Ratnaningsih, 2018).

Tahapan tanya jawab bertujuan untuk mengetahui dan mengukur pemahaman siswa terhadap materi yang baru dipelajari. Siswa dipersilakan untuk bertanya dan ditantang untuk menjawab pertanyaan. Sesekali pengajar memberikan kebebasan untuk siswa lain yang dapat menjawab pertanyaan dari temannya hal ini bertujuan agar siswa berani menyampaikan pendapat tidak peduli benar atau tidaknya, karena diakhir pembelajaran pengajar akan mereview dan meluruskan jawaban jawaban dari siswa.

Tahapan permainan (games) dan pemberian hadiah (reward), permainan ini berupa kuis (individu dan berkelompok) yang berisi soal soal dimana siswa ditantang untuk menjawabnya dalam batas waktu yang ditentukan dengan menggunakan sistem poin siswa yang berhasil mengumpulkan poin terbanyak akan mendapatkan hadiah berupa barang misalnya permen atau 
coklat. Hal ini dimaksudkan untuk memotivasi siswa agar bergairah dalam belajar. Hal ini selaras dengan penelitian (Mabruri, 2016) yang berjudul "Pengaruh Reward Terhadap Motivasi Belajar Ipa Siswa Kelas Iv Sd Muhammadiyah Piyaman” Hasil penelitian ini menunjukan ada pengaruh reward terhadap motivasi belajar IPA siswa kelas IV SD Muhammadiyah Piyaman tahun ajaran 2016/2017. Hal tersebut ditunjukkan dengan perolehan rata-rata skor motivasi kelas kontrol untuk pretest sebesar 73,2 dan posttest sebesar 76,4. Perolehan rata-rata skor motivasi kelas eksperimen untuk pretest sebesar 73,85 dan posttest sebesar 96,15. Dengan demikian terdapat perbedaan ratarata pretest-posttest pada kelas kontrol sebesar 3,2 dan pada kelas eksperimen sebesar 22,3.



Gambar 1. Kegiatan bimbingan belajar Al-Aziz kelas 2 SD

Perkembangan kognitif siswa menunjukan perkembangan yang baik, hal ini berdasarkan dari data dokumentasi nilai siswa yang semakin hari semakin baik (mengalami peningkatan), data ini diambil berdasarkan hasil tes ulangan harian dan latihan maupun tugas-tugas yang bimbingan belajar berikan. Namun, ada beberapa siswa yang tidak mengalami peningkatan nilai yaitu siswa yang mengalami nilai cenderung tetap dan siswa yang nilainya masih dibawah kkm. Hal ini dipengaruhi oleh beberapa faktor salah satunya siswa yang kurang disiplin artinya siswa tersebut jarang sekali masuk pembelajaran juga sering sekali tidak mengumpulkan tugas.

Perkembangan secara psikologis (motivasi) belajar menunjukan perkembangan yang baik. Hal ini berdasarkan hasil wawancara kepada siswa-siswa, banyak dari mereka yang antusis menceritakan keinginan mereka dalam waktu dekat, menegah dan panjang (cita-cita). Misalnya keinginan dekat mereka ingin mendapatkan peringkat semester ini, keinginan jangka menengah 
mereka ingin masuk ke SMP favorit dan keinginan jangka panjang, mereka menyebutkan cita-cita dan profesi yang akan mereka ambil nanti.

Kendala yang dihadapi selama pelaksanaan program tersebut adalah diperlukannya fasilitas yang lebih memadai seperti meja, dan pendingin ruangan dan media pembelajaran. Meja diperlukan karena sistem belajar mengajar masih lesehan sehingga akan lebih nyaman jika tersedia banyak meja. Pendingin ruangan juga diperlukan terkait dengan banyaknya jumlah siswa. Selain itu waktu yang terbatas hanya 1 jam membuat pengajar harus benar-benar menyampaikan inti dari setiap mata pelajaran. Upaya keberlanjutan program dengan mengadakan fasilitas yang memadai untuk meningkatkan kegiatan literasi siswa di luar sekolah melalui pelaksanaan kegiatan bimbingan belajar, sehingga siswa menjadi lebih nyaman dalam belajar.

\section{KESIMPULAN DAN SARAN}

Pendampingan belajar siswa melalui kegiatan bimbingan belajar ini dilaksanakan di lembaga yayasan AL-AZIZ. yang berlokasi di Rorotan III Jakarta Utara, daerah ini terkonfirmasi zona hijau oleh pemerintah setempat sehingga kami berani melakukan Kegiatan tatap muka sebagai salah satu bentuk pengabdian yang dibutuhkan masyarakat pada masa pandemi sekarang ini. Dengan jumlah seluruh siswa 56 siswa dengan rincian kelas Paud- TK tiga belas siswa, kelas 1 SD sebanyak sembilan siswa, kelas 2 SD sebanyak enam siswa, kelas 3 SD sebanyak sepuluh siswa, kelas 4 SD sebanyak lima siswa, kelas 5 SD sebanyak delapan Siswa, dan kelas 6 SD sebanyak lima siswa.

Pengabdian ini merupakan salah satu program pengabdian masyarakat bagi mahasiswa sebagai upaya pelaksanaan kegiatan kuliah kerja nyata (KKN). Kegiatan pengabdian kepada masyarakat ini memberikan banyak manfaat, wawasan dan pengetahuan kepada anak-anak terutama dalam meningkatkan prestasi dan motivasi belajar. Pelaksanaan kegiatan bimbingan belajar ini menggunakan 6 tahapan, yaitu: (1) Kerelegiusan, belajar dimulai dengan berdoa bertujuan untuk menumbuhkan pada siswa untuk segala sesuatu yang baik harus melibatkan tuhannya (2) Pemberian motivasi siswa, hal ini bertujuan untuk membangkitkan semangat belajar melalui cerita inspiratif maupun kata kata mutiara hikmah (3) Penjelasan materi, kegiatan belajar mengajar dengan berbagai metode belajar, yang kami terapkan adalah metode jigsaw dan pameran dan metode ceramah. Salah satu tujuan kami menerapkan metode ini selain agar suasana belajar monoton yaitu bisa melatih public speaking siswa dan juga melatih kerja sama antar siswa

(4) Tanya jawab hal ini bertujuan untuk mengetahui kedalaman pemahaman siswa akan materi

(5) Permainan berupa kuis individu dan cerdas cermat berkelompok, (6) Pemberian reward 
(hadiah) berupa pujian/penghargaan secara lisan dan berupa barang. Kegiatan pembelajaran ini dalam masa pandemi covid-19, ada banyak kekhawatiran dan kecemasan tertular virus.

Oleh sebab itu penulis mengharapkan adanya inovasi pembelajaran e-learning yang tingkat keefektifannya mendekati pembelajaran tatap muka sehingga tujuan capaian subjek pembelajaran dapat tercapai. Selain itu, berdasarkan evaluasi dari hasil kegiatan pendampingan belajar di rumah, untuk lebih diperhatikan pada program pendampingan belajar selanjutnya mengenai fasilitas yang nyaman agar siswa semakin semangat dalam belajar.

\section{UCAPAN TERIMA KASIH}

Pengabdian ini dapat dilaksanakan dengan baik tidak terlepas dari bantuan berbagai pihak. Oleh karena itu, iringan do'a dan ucapan terimakasih yang sebesar-besarnya penulis sampaikan kepada:

1. Evi Roviati, MP.d., Dosen pembimbing KKN-DR IAIN Syekh Nurjati Cirebon.

2. Lembaga penelitian dan pengabdian kepada masyarakat (LPPM) IAIN Syekh Nurjati Cirebon.

3. Ketua RT/RW 08/10 yang sudah mengizinkan kami melaksanakan kegiatan ini.

4. Maria Ulfah, ketua yayasan Al-Aziz.

\section{DAFTAR PUSTAKA}

Bakhri, Syaeful., Aziz, Abdul., Sarinah, Ririn. (2020). Pengetahuan dan Motivasi Untuk Menumbuhkan Minat Berinvestasi Pada Mahasiswa. Value: Jurnal Manajemen dan Akuntansi, 15(2), 60-73.

Dwi, N. P. (2013). Konstruksi Sosial Peserta Didik pada Lembaga Bimbingan Non-Formal . Jurnal Paradigma, 1, 7-15.

Mabruri, R. A. (2016). Pengaruh Reward Terhadap Motivasi Belajar IPA Siswa KelasIV SD Muhammadiyah Piyaman. Jurnal Pendidikan Guru Sekolah Dasar, 2, 64-72.

Pangestika, R. R., \& Ratnaningsih, A. (2018). Pengaruh Model Pembelajaran Kooperatif Tipe Jigsaw Pada Kemampuan Public Speaking Mahasiswa PGSD. EDUKASI : Jurnal Pendidikan, 10, 31-40.

Rosaria, D., \& Novika, H. (2017). Bimbingan Belajar Bahasa Inggris Bagi Anak Usia Sekolah Dasar (6-12 Tahun) Di Desa Semangat Dalam Rt.31 handil Bhakti. Jurnal Al-Ikhlas, 2 (2).

Santoso, A., \& Rusmawati, Y. (2019). Pendampingan Belajar Siswa di Rumah Melalui Kegiatan Bimbingan Belajar di Desa Guci Karanggeneng Lamongan. Abdimas Berdaya: Jurnal Pengabdian Masyarakat, 2, 36-43. 
Siyahailatua, S. E., \& Tarigan, M. (2020, 03 13). WHO Beri Status Pandemi untuk COVID Apa Artinya? Retrieved from TEMPO.CO: google.com/amp/s/gaya.tempo.co/amp/1319075/who-beri-status-pandemi-untuk-covid19-apa-artinya diundul tanggal 1 agustus 2020 